\title{
PERLINDUNGAN HUKUM TERHADAP JABATAN NOTARIS YANG DIDUGA MELAKUKAN MALPRAKTEK DALAM PROSES PEMBUATAN AKTA OTENTIK
}

\author{
Entin Sholikhah \\ Jawade Hafidz
}

\begin{abstract}
ABSTRAK
Notaris merupakan Pejabat Umum yang diberikan kewenangan oleh Negara dalam membuat akta Otentik. Atas dasar tersebut maka diperlukan suatu perlindungan Hukum bagi Notaris apabila dalam melaksakan tugas jabatannya diduga melakukan malpraktek dalam proses pembuatan akta otentik sebagaimana yang diatur dalam Pasal 66 ayat (1) Undangundang nomor 2 tahun 2014 tentang perubahan atas Undang-undang Nomor 30 tahun 2004 tentang jabatan Notaris (UUJN-P), tidak terdapat pengaturan yang jelas mengenai kedudukan Majelis Kehormatan Notaris (MKN) dan bentuk perlindungan Hukum yang diberikan MKN kepada Notaris. Sehingga menimbulkan permasalahan hukum yaitu bagaimana perlindungan Hukum terhadap jabatan Notaris yang diduga melakukan malpraktek dalam proses pembuatan akta otentik dan bagaimana Prosedur hukum bagi perlindungan hukumnya bagi Notaris melalui Majelis Kehormatan Notaris (MKN) dan pada masa Majelis Pengawas Daerah (MPD).

Perlindungan Hukum terhadap jabatan Notaris pada masa UUJN No 30 tahun 2004 bahwa untuk proses peradilan, penyidik, penuntut umum dan hakim dengan persetujuan MPD berwenang untuk mengambil fotocopy Minuta akta dan atau protokol Notaris yang disimpan dalam penyimpanan Noratis, sedangkan Undang-undang No 2 tahun 2014 (UUJNP) untuk proses peradilan penyidik, penuntut umum dan hakim harus memperoleh persetujuan dari Majelis Kehormatan Notaris.sedangkan untuk Prosedur Hukum bagi perlindungan Hukumnya terdapat beberapa langkah-langkah yang harus dipatuhi oleh penyidik dan Majelis Kehormatan Notaris guna menjamin kepastian dan perlindungan Hukum yang terdapat dalam pasal 66 ayat (1) UUJN-P. Hal ini dengan menggunakan suatu perbandingan kewenangan dari Majelis Pengawas Daerah (MPD) dan kewenangan dari Majelis Kehormatan Noratis (MKN).
\end{abstract}

Kata Kunci : Perlindungan Hukum, Notaris, Dugaan Malpraktek, Akta Otentik.

\section{A. Latar Belakang}

Dalam Pasal 1 angka 1 UUJN, disebutkan bahwa Notaris adalah Pejabat umum yang berwenang untuk membuat akta Otentik dan kewenangan lainnya sebagaimana dimaksud dalam Undang-undang ini. ${ }^{1}$

Kedudukan Notaris sebagai pejabat umum merupakan suatu jabatan terhormat yang diberikan oleh Negara melalui undang-undang kepada orang yang dipercayainya. Karena jabatan Notaris tidak dapat ditempatkan dilembaga eksekutif, Legislatif, ataupun yudikatif. Keberadaan lembaga notaris dikehendaki oleh aturan hukum dengan tujuan untuk melayani dan membantu masyarakat yang membutuhkan alat bukti tertulis yang bersifat otentik. Dalam pasal 1868 KHUPerdata menyatakan bahwa akta otentik merupakan akta yang dibuat dalam bentuk yang telah ditentukan oleh Undang-undang dan dibuat oleh atau dihadapan pejabat umum yang berwenang ditempat dimana akta tersebut dibuat. ${ }^{2}$

Akta otentik yang dibuat oleh Notaris tak jarang dipermasalahkan oleh salah satu pihak atau oleh pihak

\footnotetext{
${ }^{1}$ Henricus Subekti, Tugas Notaris (Perlu) Diawasi, Renvoi, Nomor 26, Tahun Ketiga, tanggal 3 April 2006, Hal 40.

${ }^{22}$ Abdul Ghofur, 2009, Lembaga Kenotariatan Indonesia, UUI Press, Yogyakarta, hal.13.
}

lain karena dianggap merugikan kepentingannya, baik itu dengan pengingkaran akan isi akta, tandatangan maupun kehadiran pihak di hadapan Notaris, bahkan adanya dugaan dalam akta otentik tersebut ditemukan keterangan palsu. Perbuatan Notaris yang diduga telah memasukkan keterangan palsu ke dalam suatu akta otentik dapat dikenakan sanksi pidana sebagaimana yang diatur dalam Kitab Undang-Undang Hukum Pidana (selanjutnya disebut KUHP). Hal ini dimungkinkan dengan begitu banyaknya jenis akta otentik yang dapat dibuat oleh Notaris, dan atas dasar tersebut dibutuhkan suatu perlindungan hukum terhadap Notaris dalam menjalankan jabatannya selaku Pejabat Umum. ${ }^{3}$

Bahwa Perlindungan Hukum terhadap Jabatan Notaris yang diduga melakukan Malpraktek dalam proses Pembuatan Akta Otentik Undang-undang Nomor 2 tahun 2014 tentang perubahan atas Undangundang Nomor 30 tahun 2004 tentang jabatan Notaris sebenarnya telah mengatur mengenai perlindungan Hukum bagi Notaris yang dilakukan oleh Majelis Kehormatan Notaris (MKN), akan tetapi pengaturan

\footnotetext{
${ }^{3}$ Sjaifurracman, 2011, Aspek Pertanggung Jawaban Notaris dalam Pembuatan Akta, Mandar Maju, Bandung, Hal 11
} 
mengenai kedudukan serta bentuk perlindungan Hukumnya tidak diatur secara tegas dalam suatu peraturan perundang-undangan, sehingga dalam hal ini terjadi kekosongan Norma dalam penegakan Hukum bagi Notaris yang harus dilakukan oleh Majelis Kehormatan Notaris (MKN).

\section{B. Rumusan Masalah}

Berdasarkan Uraian pada latar belakang masalah di atas penulis merumuskan masalah dalam penelitian sebagai berikut :

1. Bagaimanakah Perlindungan Hukum terhadap Jabatan Notaris yang diduga melakukan malpraktek dalam proses Pembuatan akta Otentik.

2. Bagaimanakah Prosedur Penegakan Hukum terhadap jabatan Notaris dalam perlindungan Hukumnya yang diduga melakukan Malpraktek dalam proses pembuatan akta otentik melalui Majelis Kehormatan Notaris menurut Undangundang Jabatan Notaris.

\section{Pembahasan}

1. Perlindungan Hukum terhadap Jabatan Notaris yang diduga melakukan Malpraktek dalam proses pembuatan akta otentik.

Dalam menjalankan fungsinya sebagai lembaga perlindungan hukum, MKN memiliki wewenang sebagaimana yang tercantum dalam Pasal 66 ayat (1) UUJN-P yang menentukan bahwa :

Untuk kepentingan proses peradilan, penyidik, penuntut umum, atau hakim dengan persetujuan Majelis Kehormatan Notaris berwenang:

a) mengambil fotokopi Minuta Akta dan/atau surat-surat yang dilekatkan pada Minuta Akta atau Protokol Notaris dalam penyimpanan Notaris; dan

b) memanggil Notaris untuk hadir dalam pemeriksaan yang berkaitan dengan Akta atau Protokol Notaris yang berada dalam penyimpanan Notaris.

Sebelumnya telah diatur pula mengenai ketentuan yang sama dalam Pasal 66 UUJN, yang menyatakan bahwa :

Untuk kepentingan proses peradilan, penyidik, penuntut umum, atau hakim dengan persetujuan Majelis Pengawas Daerah berwenang:

a) mengambil fotokopi Minuta Akta dan/atau surat-surat yang dilekatkan pada Minuta Akta atau Protokol Notaris dalam penyimpanan Notaris; dan b) memanggil Notaris untuk hadir dalam pemeriksaan yang berkaitan dengan Akta atau Protokol Notaris yang berada dalam penyimpanan Notaris.

Dari perbandingan kedua pasal tersebut, dapat diketahui bahwa, dalam ketentuan Pasal 66 ayat (1) UUJN-P hampir sama dengan ketentuan dalam Pasal 66 ayat (1) UUJN yang sebelum "dicabut" berdasarkan putusan MK Nomor 49/PUU-X/2012, hanya yang berbeda adalah lembaga atau institusi yang melaksanakan kewenangan dari pasal tersebut.

2. Bagaimanakah Prosedur Penegakan Hukum terhadap Jabatan Notaris Dalam perlindungan Hukumnya melalui Majelis Kehormatan Notaris yang diduga melakukan Malpraktek dalam Proses Pembuatan Akta Otentik Menurut Undang-undang Jabatan Notaris.

Mengenai prosedur atau tata cara pelaksanaan tugas dari MKN tersebut belum diatur secara tegas, maka dalam hal ini dapat dilakukan suatu cara atau langkah yang dapat digunakan dalam menyelesaikan kasus atau perkara yang harus ditangani melalui MKN, yaitu dengan menggunakan suatu perbandingan kewenangan dengan lembaga MPD, yang pada dasarnya merupakan lembaga yang mempunyai peran atau kewenangan yang sama dengan MKN. ${ }^{4}$

Ada beberapa langkah-langkah yang harus dipatuhi bagi penyidik maupun MKN, guna menjamin kepastian dan perlindungan hukum bagi pihak-pihak yang terkait, yaitu:

1) penyidik, penuntut umum, maupun hakim untuk kepentingan proses peradilan dapat mengambil fotokopi Minuta Akta dan/atau surat-surat yang dilekatkan pada Minuta Akta atau protokol Notais dalam penyimpanan Notaris dengan mengajukan permohonan tertulis kepada MKN, dan permohonan tersebut juga disampaikan kepada Notaris yang bersangkutan;

2) MKN berwenang melakukan pemeriksaan terhadap Notaris yang dilaporkan telah melakukan tindak pidana dalam proses pembuatan akta. 3) MKN dapat memberikan persetujuan kepada penyidik, penuntut umum maupun hakim apabila Notaris yang bersangkutan terbukti telah melakukan pelanggaran tindak pidana dalam proses pembuatan akta.

\footnotetext{
${ }^{4}$ Wawancara dengan Aris Widhihidayat, SH.,M.Kn, selaku Ketua INI Kabupaten Jepara pada tanggal 3 Pebruari 2017
} 
4) Apabila MKN tidak menemukan adanya bukti pelanggaran terkait dengan adanya dugaan tindak pidana yang dilakukan oleh Notaris tersebut, maka dalam hal ini MKN tidak dapat memberikan persetujuan bagi penyidik yang hendak memanggil Notaris tersebut.

5) Jangka waktu bagi MKN dalam memberikan persetujuan atau tidak memberikan persetujuan secara tertulis kepada penyidik adalah 30 hari sejak diterimanya surat permohonan dari penyidik (Pasal 66 ayat (3) 149 UUJN-P). Apabila dalam jangka waktu tersebut MKN tidak memberikan jawaban, maka MKN dianggap telah memberikan persetujuan (Pasal 66 ayat (4) UUJN-P).

D. Kesimpulan

Berdasarkan uraian yang dikemukakan, maka dapat diambil kesimpulan yakni sebagai berikut

1. Perlindungan Hukum terhadap Jabatan Notaris Melalui Majelis Kehormatan Notaris (MKN) dapat dilakukan secara Represif karena terkait dengan penerapan pasal 66 ayat ( 1 ) UUJN-P, yaitu dalam memberikan persetujuan atau penolak permintaan penyidik yang hendak memanggil Notaris dalam Proses Peradilan.keberadaan Majelis Kehormatan Notaris $(\mathrm{MKN})$ pada dasarnya menggantikan peran dari Majelis Pengawas Daerah (MPD) sebagai Lembaga Perlindungan Hukum terhadap Notaris bertujuan untuk menghindari tindakan yang sewenang-wenang dari penyidik yang hendak memanggil Notaris dalam persidangan. Akan tetapi dalam hal ini pengaturan mengenai kedudukan serta upaya Hukum yang diberikan oleh Majelis Kehormatan Notaris (MKN) ini belum diatur secara tegas dalam suatu peraturan perundang-undangan.

2. Prosedur Penegakan Hukum terhadap Jabatan Notaris dalam Perlindungan Hukumya melalui Majelis Kehormatan Notaris yang diduga melakukan malpraktek dalam proses pembuatan akta otentik menurut Undang-undang jabatan Notaris.

Dalam hal ini ada beberapa langkah-langkah yang harus dipatuhi bagi penyidik maupun MKN, guna menjamin kepastian dan perlindungan hukum bagi pihak-pihak yang terkait, yaitu:

1) penyidik, penuntut umum, maupun hakim untuk kepentingan proses peradilan dapat mengambil fotokopi Minuta Akta dan/atau surat-surat yang dilekatkan pada Minuta Akta atau protokol Notais dalam penyimpanan Notaris dengan mengajukan permohonan tertulis kepada MKN, dan permohonan tersebut juga disampaikan kepada Notaris yang bersangkutan;

2) MKN berwenang melakukan pemeriksaan terhadap Notaris yang dilaporkan telah melakukan tindak pidana dalam proses pembuatan akta.

3) MKN dapat memberikan persetujuan kepada penyidik, penuntut umum maupun hakim apabila Notaris yang bersangkutan terbukti telah melakukan pelanggaran tindak pidana dalam proses pembuatan akta.

4) Apabila MKN tidak menemukan adanya bukti pelanggaran terkait dengan adanya dugaan tindak pidana yang dilakukan oleh Notaris tersebut, maka dalam hal ini MKN tidak dapat memberikan persetujuan bagi penyidik yang hendak memanggil Notaris tersebut.

5) Jangka waktu bagi MKN dalam memberikan persetujuan atau tidak memberikan persetujuan secara tertulis kepada penyidik adalah 30 hari sejak diterimanya surat permohonan dari penyidik (Pasal 66 ayat (3) 149 UUJN-P). Apabila dalam jangka waktu tersebut MKN tidak memberikan jawaban, maka MKN dianggap telah memberikan persetujuan (Pasal 66 ayat (4) UUJN-P).

\section{DAFTAR PUSTAKA}

\section{A. Buku-buku}

Andasasmita, Komar, 1981, Notaris Dengan Sejarah, Peranan, Tugas, Kewajiban, Rahasia Jabatannya, Sumur, Bandung

Budiono, Herlien, 2007, Kumpulan Tulisan Hukum Perdata Di Bidang Kenotariatan, Citra Aditya Bakti, Bandung

Effendi, Bachtiar, dkk, 1991, Surat Gugat dan Hukum Pembuktian dalam Perkara Perdata, Citra Aditya Bakti, Bandung

Ghofur, Abdul, 2009, Lembaga Kenotariatan Indonesia, UUI Press, Yogyakarta

Habib, Adjie, 2008, Sanksi Perdata dan Administratif Terhadap Notaris Sebagai Pejabat Publik, Refika Aditama, Bandung

B. Peraturan Perundang-Undangan 
Undang-undang Nomor 30 Tahun 2004 Tentang Jabatan Notaris Lembaran Negara Republik Indonesia Tahun 2004 Nomor 117 Tambahan Lembaran Negara Republik Indonesia Nomor 4432

Undang-Undang Nomor 2 Tahun 2014 Tentang Perubahan Atas Undang-Undang Nomor 30 Tahun 2004 Tentang Jabatan Notaris, Lembaran Negara Republik Indonesia Tahun 2014 Nomor 3, Tambahan Lembaran Negara Republik Indonesia Nomor 5491

C. Jurnal/Artikel Ilmiah
Henricus Subekti, Tugas Notaris (Perlu) Diawasi, Renvoi, Nomor 26 Tahun Ketiga, Tanggal 3 April 2006

D. Internet

Reza Berawi, 2009, Kategori Profesi Hukum, diakses pada tanggal 24 Nopember 2016, pukul 22.10 WIB, http://id.wikipedia.org/wiki/Notaris.htm.

E. Wawancara

Wawancara dengan Ketua INI Kabupaten Jepara, Aris Widhihidayat, SH.,M.Kn, Notaris dan PPAT, pada tanggal 3 Pebruari 2017 